\title{
Pesticide Application Quality With Alternative Use of Water Sensitive Paper
}

\author{
João Paulo Tomasini Castoldi ${ }^{1}$, Diandra Ganascini ${ }^{2}$, Luciene Kazue Tokura ${ }^{3}$, Eduardo Lange Sutil ${ }^{3}$, \\ Soni Willian Haupenthal ${ }^{3}$, Bruna de Villa ${ }^{3}$, Isaque Souza Mendes ${ }^{2}$, Alessandra Mayumi Tokura Alovisi ${ }^{4}$, \\ Jessica Cristina Urbanski Laureth ${ }^{2} \&$ Márcio Furlan Maggi ${ }^{2}$ \\ ${ }^{1}$ Graduate Program in Agricultural Engineering, Western Paraná State University, Cascavel, Paraná, Brazil \\ 2 Graduate Program, Doctorate's in Degree in Agricultural Engineering, Western Paraná State University, \\ Cascavel, Paraná, Brazil \\ 3 Graduate Program, Master's in Engineering of Energy in Agriculture, Western Paraná State University, \\ Cascavel, Paraná, Brazil \\ ${ }^{4}$ Post-Graduation Program in Agronomy, Federal University of Grande Dourados, Dourados, Mato Grosso do \\ Sul, Brazil \\ Correspondence: Diandra Ganascini, Graduate Program, Doctorate's in Agricultural Engineering, Western \\ Paraná State University, Rua Universitária, 2069-Jardim Universitário, CEP: 85819-110, Cascavel, Paraná, \\ Brazil. Tel: 55-453-220-7366. E-mail: diandraganascini@hotmail.com
}

Received: February 13, 2019

Accepted: March 17, 2019 Online Published: May 15, 2019

doi:10.5539/jas.v11n6p528

URL: https://doi.org/10.5539/jas.v11n6p528

The research is financed by Capes DS, CNPq, Fundação Araucária, Fundep.

\begin{abstract}
The water sensitive paper is commonly used in the uniformity and distribution ratings of the spray droplets pattern; however, this technology still has a high cost. In this way, the present work had as objective to evaluate the quality of deposition of spray drops in different types of papers sensitive to water. The test was carried out in a wind tunnel built inside the multi-sport gymnasium of the State University of West Paraná-campus of Cascavel-PR. A semi-automated nozzle transition prototype was used to perform the tests. The variables evaluated were number of diameters, dispersion, volumetric medium diameter (VMD), droplet density, cover and droplet volume. The treatments consisted of four different types of paper compared to the water sensitive paper (control), and two nozzles. Cardboard paper stood out among the others at the cost of approximately $1 \%$ of a water-sensitive paper slip. The water sensitive paper used in agriculture can be replaced by alternative papers more economically viable and easily found in the market.
\end{abstract}

Keywords: agriculture, application, spectrum of drops, uniformity

\section{Introduction}

The use of pesticide is increasing more and more, since it is still considered the main method of control of invaders, pests and diseases in the plantations. Most of these products are liquid and spray-applied (Wang et al., 2018). The application of these inputs is part of modern agriculture and this method of control contributes to the productivity and quality of agricultural crops (Hilz \& Vermeer, 2013).

The applications consist of the deposition of spray drops on the target, however the lack of uniformity causes the inefficiency of the process. In this way, product drift can occur, causing waste and contamination of the environment (Nascimento et al., 2013). The reduction of the drift and the maximization of the deposition of the drops of the pesticides in the target is one of the main concerns of the application technique (Ferguson et al., 2015).

Silveira et al. (2008) also affirm that ensuring the efficiency of treatments and preventing losses is the main objective for controlling the factors that involve spraying. Since excess applications increase costs, they can cause crop damage and contaminate the environment. In contrast, sub-application may result in low control over the applied target and a reduction in crop yield (Sharda, Fulton, Mcdonald, \& Brodbeck, 2011). 
For uniformity of application to occur, it is essential that the maintenance of the agricultural machinery is carried out in a way that guarantees maximum execution efficiency. Another important characteristic is the correct choice of spray nozzles and their operation (Siqueira \& Antuniassi, 2011).

One of the techniques most used in studies that qualify the uniformity of spraying is through the use of water sensitive paper (Ramos, 2000).

The water sensitive paper corresponds to a surface sensitive to humidity. These yellow colored papers, when in contact with water, generate blue markings (Sadafi, Ruiz, Lucas, Jahn, \& Hooman, 2017). The change in the color of the paper is due to the presence of bromophenol blue, which in contact with water undergoes a $\mathrm{pH}$ change from 2.8 to 4.6 (Turner \& Huntington, 1970).

With the use of the water sensitive paper, it is possible to evaluate the application of the drops, by the amount and characteristic of the drops deposited in the target (Nascimento et al., 2013). By means of the diameter and the number of drops deposited on a certain area it is possible to estimate the total volume of the liquid that falls on this surface (Chaim, Maia, \& Pessoa, 1999).

The surface of the areas affected by the syrup change color, thus indicating how the defensive was applied, which facilitates the evaluation of the quality of the spray. This technique makes it possible to evaluate the quality of the application and shows a solution to make production more efficient, contributing to good practices in the field (Syngenta, 2016).

Although the use of water sensitive paper is a very widespread technique between the scientific and agricultural environment, the cost of paper with patented registration may make it unfeasible. Thus, it is necessary to search for alternatives with economic feasibility that allows the farmer to perform a simple evaluation of the applications, which are usually carried out during cultural treatments in pest and disease control.

In the market several types of papers with smaller value are available, and these can be used instead of the water sensitive paper, that in spite of its specificity, becomes costly due to the necessity of using several papers for analysis. And this alternative comes together to minimize costs for farmers who wish to use the technique to assess the uniformity, drift and quality of application in the field. Therefore, the objective of this work was to search for viable alternatives in substitution of the water sensitive paper to reduce the cost of utilization and to evaluate the technical feasibility of the use of the alternative papers in the applications of the pesticides.

\section{Method}

The experiment was conducted at the Western Paraná State University- Unioeste, in a covered multi-gymnasium belonging to the campus of Cascavel-PR. The experiment was carried out using the prototype of embedded automation of terrestrial bar sprayers for the application of low-cost agricultural pesticides, which has three sections (bars B1, B2 and B3, each with 2.65 meters). Each bar uses a set of nozzles, with a distance of 0.50 meters between them, and five spray tips, two of them with flat fan type (models BD-02 and BD-015) and one cone type (model CV-IA-015), both produced by the company Magnojet ${ }^{\circledR}$.

The prototype was produced at the Defensive Application Technology Laboratory of UNIOESTE campus in Cascavel, PR (Figure 1).

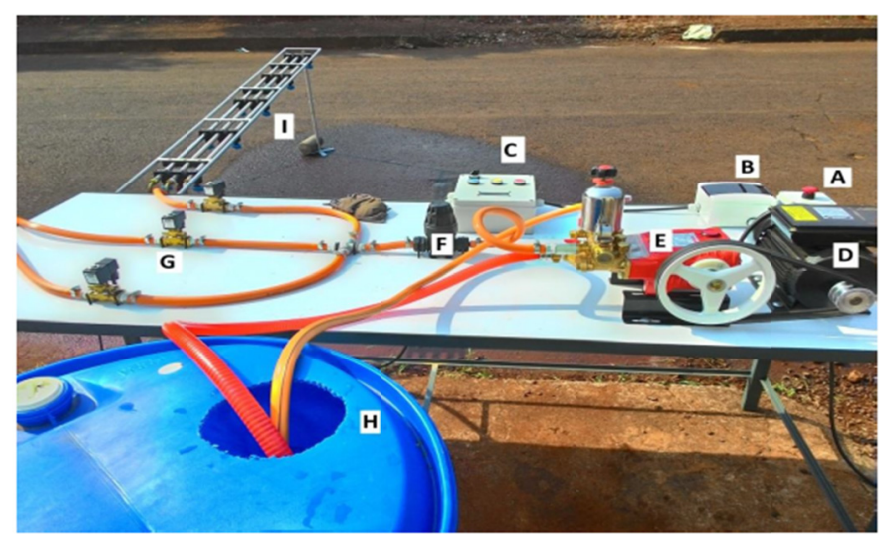

Figure 1. Control stand: safety shut-off button (A), system switch (B), control module (C), motor (D), spray pump $(\mathrm{E})$, filter $(\mathrm{F})$, solenoid valve $(\mathrm{G})$, reservoir $(\mathrm{H})$, bar and spray nozzles $(\mathrm{I})$ 
A wind tunnel with dimensions of $15 \times 2 \times 2$ meters (length, width and height, respectively) was constructed. The tunnel structure was constructed in wood (pinus), the roof and sides of the tunnel were closed using black plastic canvas $(200 \mu \mathrm{m})$ of polyethylene and low density, with both ends open to facilitate airflow. The constructed wind tunnel was based on the model described by Fietsam, Young, and Steffen (2004), specifically for trials in agriculture (Figure 2).

Four types of water-sensitive papers were used: sulphite, cardboard, paperboard and rives tradition 250 . The commercial water sensitive paper was the control (control) treatment. All papers were sized in the standard size of commercial water-proof papers, $76 \times 26 \mathrm{~mm}$.

Sulphite paper (Chamex office ${ }^{\circledR}$ ) also called parchment or Offset, is the type of common white paper used for printing. It can have several colors and sizes, the most common being the A4 size $(21 \mathrm{~cm} \times 29.7 \mathrm{~cm})$ white. Its name is given due to the addition of sulphite. The weight of this paper is $75 \mathrm{~g} \mathrm{~cm}^{-2}$.

Cardboard paper (Multiverde ${ }^{\circledR}$ ) is characterized by being a type of thick, rigid and compact paper, widely used for making boxes and packaging. The weight is $180 \mathrm{~g} \mathrm{~cm}^{-2}$.

Cardboard paper (Holler $\left.{ }^{\circledR}\right)$ is manufactured for various uses, such as the preparation of paint panels, the creation of notices and school work, with a weight of $120 \mathrm{~g} \mathrm{~cm}^{-2}$.

Rives tradition (Antalis Brasil S.A. ${ }^{\circledR)} 250$ paper is a white paper with texture, being more used in the making of wedding invitations. It has a weight of $250 \mathrm{~g} \mathrm{~cm}^{-2}$.

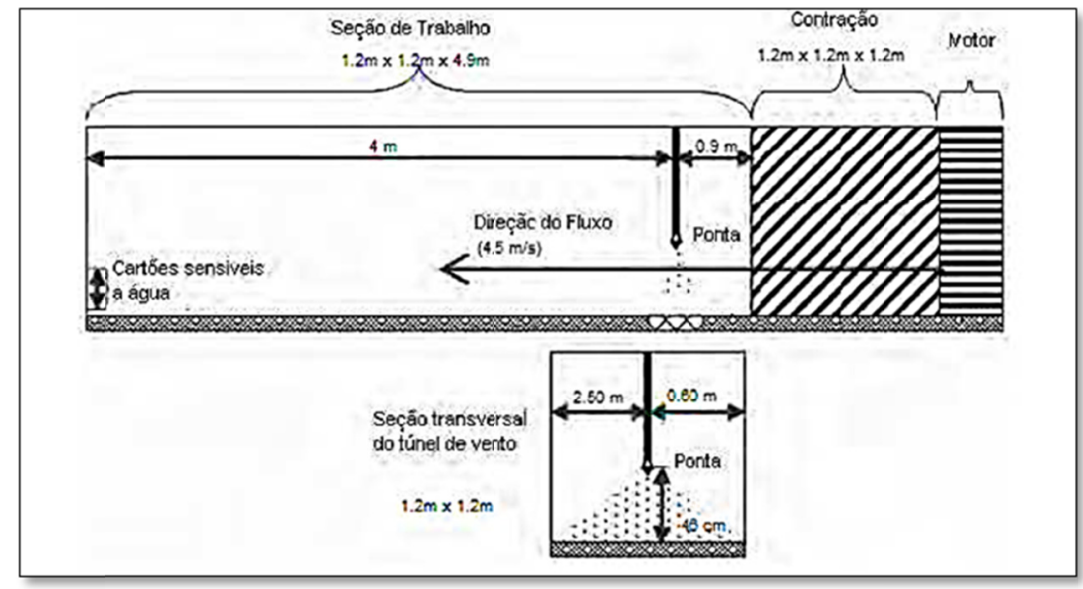

Figure 2. Wind tunnel constructed by Fietsam, Young and Steffen (2004)

The syrup used in the evaluations consisted of water and liquid dye of the trademark Xadrez, in blue and black colors, in order to color the papers tested with the spray syrup. This highlights the drops on the white surfaces of the papers for the data digitization.

A wooden cart was constructed to fix the papers with a $1.20 \mathrm{~m}$ slat in the center and five slats spaced $30 \mathrm{~cm}$ apart to facilitate the movement of the papers under the spray bars, since they were fixed inside the tunnel of wind so as not to be subject to wind interference. To make the movement of the cart was tied a rope in the central lath and used a study table to serve as pulley, thus increasing and standardizing the speed traveled. An average velocity of $4 \mathrm{~m} . \mathrm{s}^{-1}$ was used for the two passes, this velocity was calculated by means of a distance known for the time it took to be traversed. Two passes were made, one for each type of beak, with 5 repetitions each. Five papers of each type (water sensitive paper, cardboard, paperboard, sulphite and rives tradition 250) were used, totaling 45 papers per pass.

To collect the data with the spray nozzles of the two bars, the working pressure was defined, according to the manufacturer's recommendation of 4.1 bar. The pressure chosen also considered a pressure that both nozzles would accept, following manufacturer's recommendations.

Table 1 shows the technical recommendations of each manufacturer and for each type of spray tip used. 
Table 1. Technical characteristics of the spray tips provided by the manufacturer (Insert year of publication of the manufacturer's catalog)

\begin{tabular}{lll}
\hline Parameters & BD-015 & CV-IA-015 \\
\hline Pressure range $(B a r)$ & $1-4.1$ & $3.1-10.4$ \\
Height $(\mathrm{cm})$ & $50-60$ & $50-60$ \\
Spanking $(\mathrm{cm})$ & 50 & 50 \\
Angle & 110 & 100 \\
Flow rate $\left(\mathrm{mL} \mathrm{min}^{-1}\right)$ & 700 & 700 \\
Type & Fan & Cone \\
Manufacturer & Magnojet ${ }^{\circledR}$ & Magnojet ${ }^{\circledR}$ \\
\hline
\end{tabular}

After the calibration of the equipment, the tests were started. The equipment was activated, and for its stabilization it was waited 5 seconds. Once stabilized, the movement of the cart was started, simulating the drag with the different types of paper. The trolley passed under the bar that was static for spraying the syrup on the test papers, this process was repeated for both types of nozzles, following the same test pattern.

Thus, after the spraying procedure, the test papers were collected, for the measurement of the drop spectra for the two types of nozzles in two stages.

Soon after the passage of the cart, the test papers were collected and scanned, because as they are sensitive to the humidity of the air, it was tried to scan as quickly as possible. The papers were scanned on a HP 3180 Hewlett-Packard ${ }^{\circledR}$ scanner (with a minimum resolution of 600 dpi), and the images were cut and processed in the Quant software.

Quant software processes from photos obtained by satellites to those made by microscopes and allows the application of filters, contrast and operations between channels to fit the images, because the surfaces of the papers tested are white, the individual images of each paper were processed in the software Quant in order to match the color of the water sensitive paper to be processed in the Drops software (Version 2.2, Embrapa). The program analyzes the deposition of pesticides to determine the number of droplets, number of diameters, dispersion, volumetric medium diameter (VMD), droplet density $\left(\right.$ drops $\left.\mathrm{cm}^{-2}\right)$, cover $(\%)$ and droplet volume (L $\left.h^{-1}\right)$.

The statistical design used was a $2 \times 5$ factorial, two types of nozzles and five types of paper. The results were obtained by ANOVA and the means were compared by Tukey's test at 5\% of significance, using Sisvar 5.6 software (Ferreira, 2015). We also used the software GOTAS Version 2.2, (Embrapa, 2010) for the analysis of the papers.

The software Quant produced photos by means of satellites up to them by microscopes and enabled the application of filters, contrast and operation between channels for images such as the clouds of the papers tested, as individual images of each paper were processed in the Quant software in order to match.

\section{Results}

Table 2 shows the interactions according to analysis of variance (ANOVA). From the ANOVA, it was verified by means of test $\mathrm{f}$, that both types of BD-015 and CVIA-015 nozzles do not differ statistically from each other ( $\mathrm{p}>$ 0.05 ), for any type of paper, that is, none of the nozzles was influenced by the response variable. Therefore, the papers tested are different $(\mathrm{p}<0.05)$, that is, at least one pair of papers are different, so at least one type of paper was influenced by the response variable.

Table 2. Analysis of variance of the treatments studied $(\mathrm{N}=50)$

\begin{tabular}{llllll}
\hline Source of variation & DF & Sum of squares & Mean square & F & P \\
\hline Beak & 1 & 4685.12 & 4685.12 & 1.38 & 0.2480 \\
Paper & 4 & 560006.88 & 140001.72 & 41.2 & $0.0000^{*}$ \\
Repetitions & 4 & 3535.48 & 883.87 & 0.26 & 0.9015 \\
X-Beverage Treatment & 4 & 8642.08 & 2160.52 & 0.64 & 0.6402 \\
Residue & 36 & 122299.72 & 3397.21 & - & - \\
\hline Total corrected & 49 & 699169.28 & & \\
CV $(\%)=24.38$ & & & & \\
Average overall: 239.12 & &
\end{tabular}

Note. ${ }^{*}$ level of significance used in the $\mathrm{F}$ test: $5 \%$. 


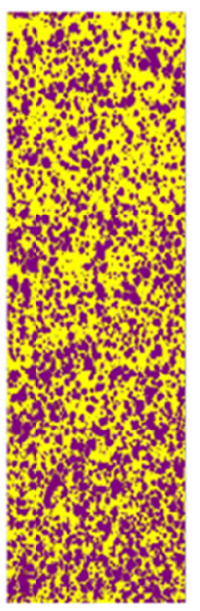

$\mathrm{H}$

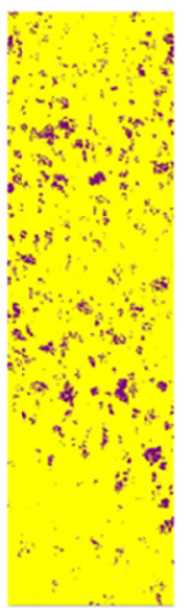

$\mathrm{s}$

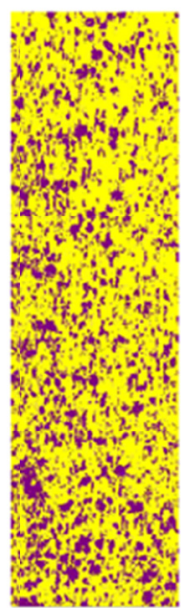

$\mathrm{Ct}$

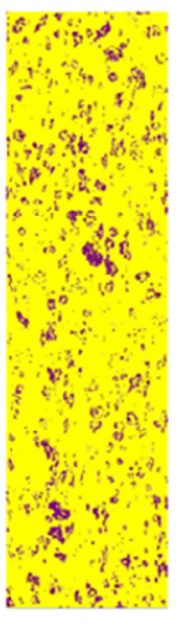

C

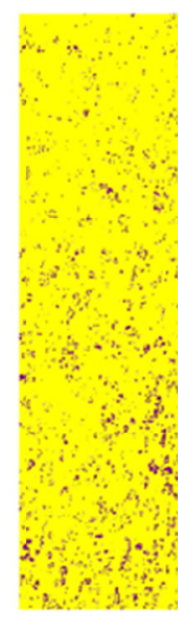

Rt

Figure 3. Papers spraying pattern treated in the Quant (H: hydrosensitive, S: sulphite, Ct: Card, C: paperboard, Rt: rives tradition 250 )

Table 3. Comparisons of the means of the parameters number of diameters, dispersion, volume, density, coverage and volumetric median diameter (VMD) for the five treatments studied

\begin{tabular}{|c|c|c|c|c|c|c|}
\hline Treatment & Number of diameters & Dispersion & Volume & Density & Coverage & VMD \\
\hline & & & $\mathrm{L} \mathrm{ha}^{-1}$ & drops $\mathrm{cm}^{-2}$ & $\%$ & \\
\hline Hydrosensitive (control) & $402 \mathrm{a}$ & $1.85 \mathrm{a}$ & $259.4 \mathrm{a}$ & $260.89 \mathrm{a}$ & 38 & $628.4 \mathrm{a}$ \\
\hline Card & $317 \mathrm{~b}$ & $1.43 \mathrm{~b}$ & $145.2 \mathrm{~b}$ & $205.86 \mathrm{ab}$ & 24 & $586.1 \mathrm{a}$ \\
\hline Carton & $197 \mathrm{c}$ & $1.42 \mathrm{~b}$ & $53.1 \mathrm{c}$ & $167.18 \mathrm{bc}$ & 10 & $402.4 \mathrm{~b}$ \\
\hline Rives T. 250 & $172 \mathrm{~cd}$ & $1.27 \mathrm{~b}$ & $32.4 \mathrm{c}$ & $138.77 \mathrm{bc}$ & 7 & $318.2 \mathrm{bc}$ \\
\hline Sulphite & $108 \mathrm{~d}$ & $1.35 \mathrm{~b}$ & $14.1 \mathrm{c}$ & $124.73 \mathrm{c}$ & 4 & $238.4 \mathrm{c}$ \\
\hline
\end{tabular}

Note. ${ }^{*}$ Equal letters in the column represent averages statistically equal to $5 \%$ of significance, by Tukey's test.

Table 3 shows the comparisons of the means of the analyzed variables. For the number of diameters, the water sensitive paper (control) collected 402 diameters and this was statistically larger than the others. Oliveira (2017) in tests with water sensitive paper found values lower than 400 diameters with the types of nozzles tested. Among the other papers, the paper presented 317 diameters with values close to those of the water sensitive paper.

It is observed that for the dispersion the sulphite paper with a value of 1.85 presents the highest value between the papers, this is due to the weight of this paper being smaller, resulting in the better spreading of the liquid of the syrup. The other papers were statistically equal to the paper considered standard (water sensitive paper), making possible the substitution of these papers valid for the dispersion test of agrochemicals. Oliveira (2017) in similar work found near dispersion values by testing water sensitive paper with the same types of nozzles.

The water sensitive paper presented higher volume collection $\left(259 \mathrm{~L} \mathrm{ha}^{-1}\right)$, therefore, statistically higher than the others, and the paper that came closest was the card $\left(145 \mathrm{~L} \mathrm{ha}^{-1}\right)$, but statistically different and smaller than the control, with approximately $56 \%$ less. The other papers (paperboard, rives tradition 250 and sulphite) were lower than the control and statistically equal among them.

For Cunha, Texeira, Coury and Ferreira (2003), the spray volume directly influences the size of the droplet, and the larger the spray volume, the larger the drop and the smaller the volume produces smaller droplets susceptible to drift loss and evaporation. However, Morais et al. (2016) reported different results than expected, with a decrease in number and density of droplets with higher application volumes. External variables, such as weather conditions, may interfere with the number and size of droplets.

It is verified that the only paper that did not differ from the water sensitive paper in terms of density was the paperboard that presented a value of 205.86 drops $\mathrm{cm}^{-2}$, the other papers did not statistically equate with the control paper with a significant minimum difference (SMD) of 74.4 drops $\mathrm{cm}^{-2}$. It can be observed that the water sensitive paper had a higher density (260 drops $\left.\mathrm{cm}^{-2}\right)$ when compared to paperboard (205 drops $\left.\mathrm{cm}^{-2}\right)$, 
approximately $80 \%$ larger. In this case the papers (cardboard, paperboard and sulphite) can replace the water sensitive paper in the collection of density. Scudeles, Raetano, and Araújo (2004), studied sthephon spray (growth accelerator) in coffee trees, these authors obtained mean droplet densities of 30 to $60 \mathrm{~cm}^{-2}$ drops in the upper part of the plant and 217 to $230 \mathrm{~cm}^{-2}$ drops in using Arbus 400 equipment and JA2 nozzles (corresponding to $\left.200 \mathrm{~L} \mathrm{ha}^{-1}\right)$.

The water sensitive paper presented a higher percentage of coverage (38\%), being statistically higher than the others, which was closer to that of paper, but statistically different and smaller than the control sample (24\%). The papers (paperboard and rives tradition 250) were lower than the control and statistically equal, as were the papers (rives tradition 250 and sulphite). The current coverage values were higher than those obtained by Ramos et al. (2007) on citrus leaves using an Arbus 2000 spray at variable volumes of 50 to $200 \mathrm{~L} \mathrm{ha}^{-1}$.

The water sensitive paper and paperboard were statistically the same, with a minimum significant difference of $159 \mu \mathrm{m}$, where the water sensitive paper had VMD of $629 \mu \mathrm{m}$ and the paperboard had $586 \mu \mathrm{m}$, paper (paperboard and rives tradition 250) were lower than the control and statistically equal, as well as the roles (rives tradition 250 and sulphite), which differs to the values found by Cunha, Teixeira and Ferreira (2003) in a similar work in which it evaluated, among other parameters, the VMD, in which it found values that varied from 83 to $129 \mu \mathrm{m}$ when the empty conical jet nozzles were used, and from 124 to $214 \mu \mathrm{m}$ in the flat jet nozzles.

\section{Conclusions}

The water sensitive paper used in agriculture can be replaced by alternative papers more economically viable and easily found in the market.

The paper presented more expressive and similar results to the water sensitive paper, at the cost of approximately $1 \%$ of a paper of the water sensitive paper.

\section{Acknowledgements}

The Unioeste for the support, structure and research opportunity. A Capes, CNPq, Fundep, Fundação Araucária for supporting the development of the research.

\section{References}

Chaim, A., Maia, A. H. N., \& Pessoa, M. C. P. Y. (1999). Estimativa da deposição de agrotóxicos por análise de gotas. Pesquisa Agropecuária Brasileira, 34(6), 962-969. https://doi.org/10.1590/S0100-204X19990006 00006

Cunha. J. P. A. R., Teixeira, M. M., Coury, J. R., \& Ferreira, L. R. (2003). Avaliação de estratégias para redução da deriva de agrotóxicos em pulverizações hidráulicas. Planta Daninha, 21(2), 325-332. https://doi.org/ $10.1590 / \mathrm{S} 0100-83582003000200019$

Embrapa (Empresa Brasileira de Pesquisa Agropecuária). (2010). Software Gotas. Retrieved from http://www. cnpma.embrapa.br

Ferguson, J. C., O'donnell, C. C., Chauhan, B. S., Adkins, S. W., Kruger, G. R., Wang, R., ... Hewitt, A. J. (2015). Determining the uniformity and consistency of droplet size across spray drift reducing nozzles in a wind tunnel. Crop Protection, 76, 1-6. https://doi.org/10.1016/j.cropro.2015.06.008

Ferreira, D. F. (2015). Sisvar. Versão 5.6. Lavras: UFLA/DEX.

Fietsam, J. F. W., Young, B. G., \& Steffen, R. W. (2004). Herbicide drift reduction to drift control agents with glyphosate. Transactions of the American Society of Agricultural Engineers, 47(5), 1405-1411. https://doi.org/10.13031/2013.17605

Hilz, E., \& Vermeer, A. W. P. (2013). Spray drift review: The extent to which a formulation can contribute to spray drift reduction. Crop Protection, 44, 75-83. https://doi.org/10.1016/j.cropro.2012.10.020

Morais, J. L. C., Castellani, M. A., Raetano, C. G., De Macedo, J. A., Nery, M. S., \& Moreira, G. L. P. (2016). Lambda-cyhalothrin efficiency on fruit borer control and quali-quantitative spraying aspects in a pine cone crop. Ciência e Agrotecnologia, 40(3), 288-297. https://doi.org/10.1590/1413-70542016403044415

Nascimento, A. B., Oliveira, G. M., Fonseca, I. C. B., Saab, O. J. G. A., \& Canteri, M. G. (2013). Determinação do tamanho da amostra de papeis hidrossensíveis em experimentos ligados a tecnologia de aplicação. Semina, 34(6), 2687-2696. https://doi.org/10.5433/1679-0359.2013v34n6p2687 
Oliveira, W. D. (2017). Deriva em túnel de vento com diferente espectro de gotas (Unpublished Monograpy, University of Graduação em Engenharia Agrícola, Ciências Agrarias, State University of Western Paraná, Cascavel, Paraná, Brazil).

Ramos, H. H. (2000). Tecnologia de aplicação de agrotóxicos. Fitopatologia Brasileira, 25, 275-283.

Ramos, H. H., Yanai, K., Araújo, D., \& Aguiar, V. C. (2007). Tecnologia de aplicação de defensivos na cultura do café. In Curso de Atualização em Café, Campinas, São Paulo, Brazil.

Sadafi, M. H., Ruiz, J., Lucas, M., Jahn, I., \& Hooman, K. (2017). Numerical and experimental study on a single cone saline water spray in a wind tunnel. International Journal of Thermal Sciences, 120, 190-202. https://doi.org/10.1016/j.ijthermalsci.2017.06.011

Scudeler, F., Raetano, C. G., Araujo, D. de, \& Bauer, F. C. (2004). Cobertura da pulverização e maturação de frutos do cafeeiro com ethephon em diferentes condições operacionais. Bragantia, 129-139. https://doi.org/10.1590/S0006-87052004000100013

Sharda, A., Fulton, J. P., Mcdonald, T. P., \& Brodbeck, C. J. (2011). Real-time nozzle flow uniformity when using automatic section control on agricultural sprayers. Computers and Electronics in Agriculture, 79(2), 169-179. https://doi.org/10.1016/j.compag.2011.09.006

Silveira, J. C da. M., Filho, A. G., Pereira, J. O., Silva, S. L., \& Modolo, A. J. (2008). Avaliação qualitativa de pulverizadores da região de Cascavel, Estado do Paraná. Acta Scientiarum Agronomy, 28(4), 569-573.

Siqueira, J. L., Antuniassi, U. R. (2011). Inspeção periódica de pulverizadores nas principais regiões de produção de soja no Brasil. Revista Energia na Agricultura, 26(4), 92-100. https://doi.org/10.17224/EnergAgric. 2011v26n4p92-100

Syngenta. (2016). Papel Hidrossensivel. Retrieved from http://www3.syngenta.com

Turner, C. R., \& Huntington, K. A. (1970). He uses of water sensitive dye for the detection and assessment of small spray droplets. Journal of Agricultural Engineering Research, 15(4), 385-287. https://doi.org/ 10.1016/0021-8634(70)90099-5

Wang, F., Hu, Z., Abarca, C., Fefer, M., Liu, J., Brook, M. A., \& Pelton, R. (2018). Factors influencing agricultural spray deposit structures on hydrophobic surfaces. Colloids and Surfaces A: Physicochemical and Engineering Aspects, 553, 288-294. https://doi.org/10.1016/j.colsurfa.2018.05.074

\section{Copyrights}

Copyright for this article is retained by the author(s), with first publication rights granted to the journal.

This is an open-access article distributed under the terms and conditions of the Creative Commons Attribution license (http://creativecommons.org/licenses/by/4.0/). 